\title{
Optimizing Harvest Time Through Absolute and Relative Growth of the Black Clam, Chionista fluctifraga, Cultivated in the Intertidal Along the Southeastern Coast of the Gulf of
} California

\author{
Andrés Martín Góngora-Gómez ${ }^{1}$ (D) , María José Acosta-Campos ${ }^{2} \mathbb{D}$, María Fernanda Navarro- \\ Chávez $^{1}$ (D), Hervey Rodríguez-González ${ }^{1}$, Lizeth Carolina Villanueva-Fonseca ${ }^{1}$ (D) Brenda Paulina \\ Villanueva-Fonseca ${ }^{2}$ (D) Manuel II García-Ulloa ${ }^{3}$, Juan Antonio Hernández-Sepúlveda ${ }^{1}$ (i), \\ Manuel García-Ulloa ${ }^{1, *}$ (iD
}

\footnotetext{
${ }^{1}$ Instituto Politécnico Nacional. Centro Interdisciplinario de Investigación para el Desarrollo Integral Regional-Unidad Sinaloa., Aquaculture, Guasave/Sinaloa, Mexico.

2Universidad Autónoma de Occidente, Unidad Regional Guasave, Environment, Guasave/Sinaloa, Mexico. ${ }^{3}$ Universidad Nacional Autónoma de México, Instituto de Ecología, Ciudad de México/CDMX, Mexico.
}

How to cite

Góngora-Gómez, A.M., Acosta-Campos, M.J.A., Navarro-Chávez, M.F., Rodríguez-González, H., Villanueva-Fonseca, L.C., Villanueva-Fonseca, B.P., García-Ulloa, M. II, Hernández-Sepúlveda, J.A., García-Ulloa, M. (2022). Optimizing Harvest Time Through Absolute and Relative Growth of the Black Clam, Chionista fluctifraga, Cultivated in the Intertidal Along the Southeastern Coast of the Gulf of California. Turkish Journal of Fisheries and Aquatic Sciences, 22(2), TRJFAS19537. http://doi.org/10.4194/TRJFAS19537

\section{Article History}

Received 30 March 2021

Accepted 14 September 2021

First Online 27 September 2021

\section{Corresponding Author}

Tel.: +6878729626

E-mail: turbotuag@hotmail.com

\section{Keywords}

Morphometric relationships

Relative growth

Venus clam

Molluscan aquaculture

\begin{abstract}
The shell height-body weight relationship of the black clam Chionista fluctifraga cultivated in the intertidal of the southeastern Gulf of California, was evaluated for the first time, to improve the knowledge in determining its harvesting time. Clam seeds $(\mathrm{n}=900,000 ; 6.1 \pm 1.9 \mathrm{~mm}$ ) were produced in the laboratory. The culture was divided into pre-fattening in racks on the bottom ( 2 months) and fattening directly in the bottom (16 months) from May 2018 to October 2019. Each month, $60(n=1080)$ clams were randomly selected to stablish the morphometric relationship between shell height (SH) and body weight (BW). The growth rate $(\mathrm{mm} / \mathrm{d}$ and $\mathrm{g} / \mathrm{d})$ was recorded. The SH-BW Interaction in both cultivation phases showed positive allometry. SH in prefattening and fattening registered a growth rate of 0.072 and $0.058 \mathrm{~mm} / \mathrm{d}$, respectively. In fattening, the interaction BW-SH displayed a high coefficient of determination $\left(R^{2}=0.99\right)$. A final survival rate of $90 \%$ was obtained. The results yielded the equations that describe the relative growth of $C$. fluctifraga for the fattening stage. A harvesting time after 10 months of fattening in the intertidal zone is stablished to reach the commercial size ( $35 \mathrm{~mm}, \mathrm{SH}$ ).
\end{abstract}

\section{Introduction}

Contrary to species that require an elaborated diet, in the cultivation of bivalve mollusks, profitability is not affected by food, instead by 1 ) the biology and genetics of the species, 2) environmental conditions (parameters, biological interactions), 3) size demanded by the market, and 4) management (planting density, cleaning, days of cultivation, biometrics, harvest time) (Munroe \& McKinley, 2007; Saurel et al., 2014), among other factors. Obtaining the shell measurements and body weight during cultivation allows establishing morphometric relationships that can help to determine the harvesting time.
Morphometric relationships represent a useful method to evaluate the relative growth and performance of bivalves in both the natural environment (Ngor et al., 2018) and under culture conditions (Nerlović et al., 2016), since it is a simple, non-invasive procedure that can be easily performed in the field (Gaspar et al., 2001). As part of the routine work in a mollusk farm, estimating the shell measurements and weight of a representative sample of the population allows obtaining mathematical equations that relate the different dimensions of the organisms (Mohammed et al., 2019; Yusof et al., 2020). The collection of at least one single measurement to be incorporated into previously established equations 
could help estimating the remaining morphometric variables (Babaei et al., 2010; Góngora-Gómez et al., 2018), to relate the ideal cultivation conditions with the proportional growth of bivalves (Ríos-Jara et al., 2019), and to establish a relationship between the time of culture and the optimal size of the organism for the best harvesting time (Biona et al., 2017).

The black clam Chionista fluctifraga (Sowerby II, 1853) is distributed from Santa Barbara, California, in the USA, to the peninsula and the Gulf of California, in Mexico (Coan \& Valentich-Scott, 2012). This bivalve represents a source of protein for the coastal communities of North-Central Sinaloa, in northwestern Mexico, where it is commonly sold at US $\$ 2.0-2.5 / \mathrm{kg}$ (pers. comm.). The high demand for this clam by the USA market (Chávez-Villalba et al., 2019) has prompted interest for its cultivation on a large scale, which has generated basic information that includes the study of its bioecology (Martínez- Córdoba, 1988), the production of $C$. fluctifraga in polyculture within shrimp ponds (Martínez-Córdoba \& Martínez-Porchas, 2006; Martínez-Córdoba et al., 2013), and its use as a bioremediator of aquaculture effluents (MartínezCórdoba et al., 2011). Only Castillo-Durán et al. (2016) evaluated the growth and survival of sedes, produced in the laboratory, to their commercial size ( $35 \mathrm{~mm})$, in a cultivation suspended within a coastal lagoon.

The available studies of clam cultivation in the intertidal zone include aspects such as the influence of environmental conditions on growth (Lavoie et al., 2016), the physiological performance of bivalves due to aireal exposure (Yin et al., 2017), the assessment of potential places for controlled production (Talley et al., 2015), and the types and phases of cultivation (Zhang \& Yan, 2006; Toniello et al., 2019), among others. In 2018, a private company in northwest Mexico implemented an intensive culture of $C$. fluctifraga seeds produced in the laboratory (García-Ulloa et al., 2018). The objective of this work is to describe for the first time, the absolute and relative growth of the black clam in its two cultivation phases (pre-fattening and fattening) in an intertidal zone of the southeastern Gulf of California, using shell height and body weight, to contribute with relevant information related to its harvesting time.

\section{Materials ans Methods}

\section{Cultivation Area}

The cultivation area (3.7 hectares) is located in $\mathrm{El}$ Colorado Bay, Municipality of Ahome, Sinaloa, Mexico. The intertidal plot is geographically delimited by the following coordinates: $25^{\circ} 43^{\prime} 46.30^{\prime \prime} \mathrm{N}$ and $109^{\circ} 33^{\prime} 54.50^{\prime \prime} \mathrm{W} ; 25^{\circ} 43^{\prime} 46.50^{\prime \prime} \mathrm{N}$ and $109^{\circ} 33^{\prime} 50.40^{\prime \prime} \mathrm{W}$; $25^{\circ} 43^{\prime} 38.70^{\prime \prime} \mathrm{N}$ and $109^{\circ} 23^{\prime} 47.80^{\prime \prime} \mathrm{W}$; and $25^{\circ} 43^{\prime} 36.30^{\prime \prime} \mathrm{N}$ and $109^{\circ} 23^{\prime} 52.80^{\prime \prime} \mathrm{W}$ (Figure 1a). The seeds of C. fluctifraga $(n=900,000)$ were produced in laboratory and were sown during the second half of April 2018. Cultivation lasted 18 months (May 2018-October 2019).

\section{Pre-fattening on Racks and Fattening on the Sand}

The seeds were transported dry $\left(18^{\circ} \mathrm{C}\right.$, for 90 minutes) from the laboratory to the intertidal plot, adapted to local conditions (Helm et al., 2006), and placed in wooden racks $(1.20 \times 0.60 \mathrm{~m})$ covered with mosquito net ( $2 \mathrm{~mm}$ in diameter), adjusting the density to 4,000 seeds $(6.1 \pm 1.9 \mathrm{~mm}$ in shell height) per rack. The racks were aligned in the sand according to the direction of the tide within the bay (N-S).

A sack filled with sand at half its capacity was placed on top of each rack, to prevent them from being displaced during high tide (Figure $1 \mathrm{~b}$ ). Every month, the racks were brushed to remove the sludge deposit and the fixed epibionts (algae, sponges, barnacles, etc). The pre-fattening period lasted 2 months (May-June 2018). To carry out bottom seeding, the clams were sorted by size using a sieve and only those above $9 \mathrm{~mm}$ in shell height were placed on the sand at a density of 420 clams $/ \mathrm{m}^{2}$. For this, a tractor built lines of $1.20 \mathrm{~m}$ wide to sow the clams, placing on top of them, a plastic mesh against predators ( $170 \mathrm{~m}$ long $\times 1.40 \mathrm{~m}$ wide, 6 to $10 \mathrm{~mm}$ diameter of opening) (Figure 1c). A total of 13 lines ( $\approx$ 70,000 clams/line) were seeded. The maintenance and cleaning of meshes was carried out manually every month. Fattening lasted 16 months (July 2018-October 2019).

\section{Environmental Conditions}

In both cultivation stages, the physicochemical parameters were obtained in situ at the day of collecting the samples once tide was high (1.20 $\mathrm{m}$ depth). The parameters were: water temperature $\left({ }^{\circ} \mathrm{C}\right)$ and dissolved oxygen $(\mathrm{mg} / \mathrm{mL}$ ) with an oximeter (YSI-5/12FT, Yellow Springs, $\mathrm{OH}, \mathrm{USA}$ ); $\mathrm{pH}$ with a potentiometer (HANNA, Hanna Instruments, Woonsocket, RI, USA), and salinity (psu) with a precision refractometer (Atago, USA Inc. Bellevue, WA, USA).

Water samples were also taken to determine total suspended solids (TSS), particulate organic matter (POM, Rice et al., 2017), and concentration of chlorophyll $a(\mathrm{Cl}-a)$. For the latter, the water was filtered (Whatman GF/F $0.7 \mu \mathrm{m}$ ) with a vacuum pump and $\mathrm{Cl}-a$ was determined through spectrophotometry according to Strickland and Parsons (1972) for seawater.

\section{Absolute and Relative Growth}

One of the 13 sown lines for the fattening was destined to collect the clams that were measured and weight each month. For this, a $1.0 \mathrm{~m}^{2}$ quadrat was placed $10 \mathrm{~m}$ away from the sampling carried out in the previous month, to cover almost the entire $170 \mathrm{~m}$ of the plastic line, along the 16 months of fattening. Each month, in the two cultivation stages, 60 clams were randomly selected to obtain their biometrics. With a Vernier calliper $(0.01 \mathrm{~mm})$, the shell height $(\mathrm{SH}$, the maximum distance from the umbo to the ventral 

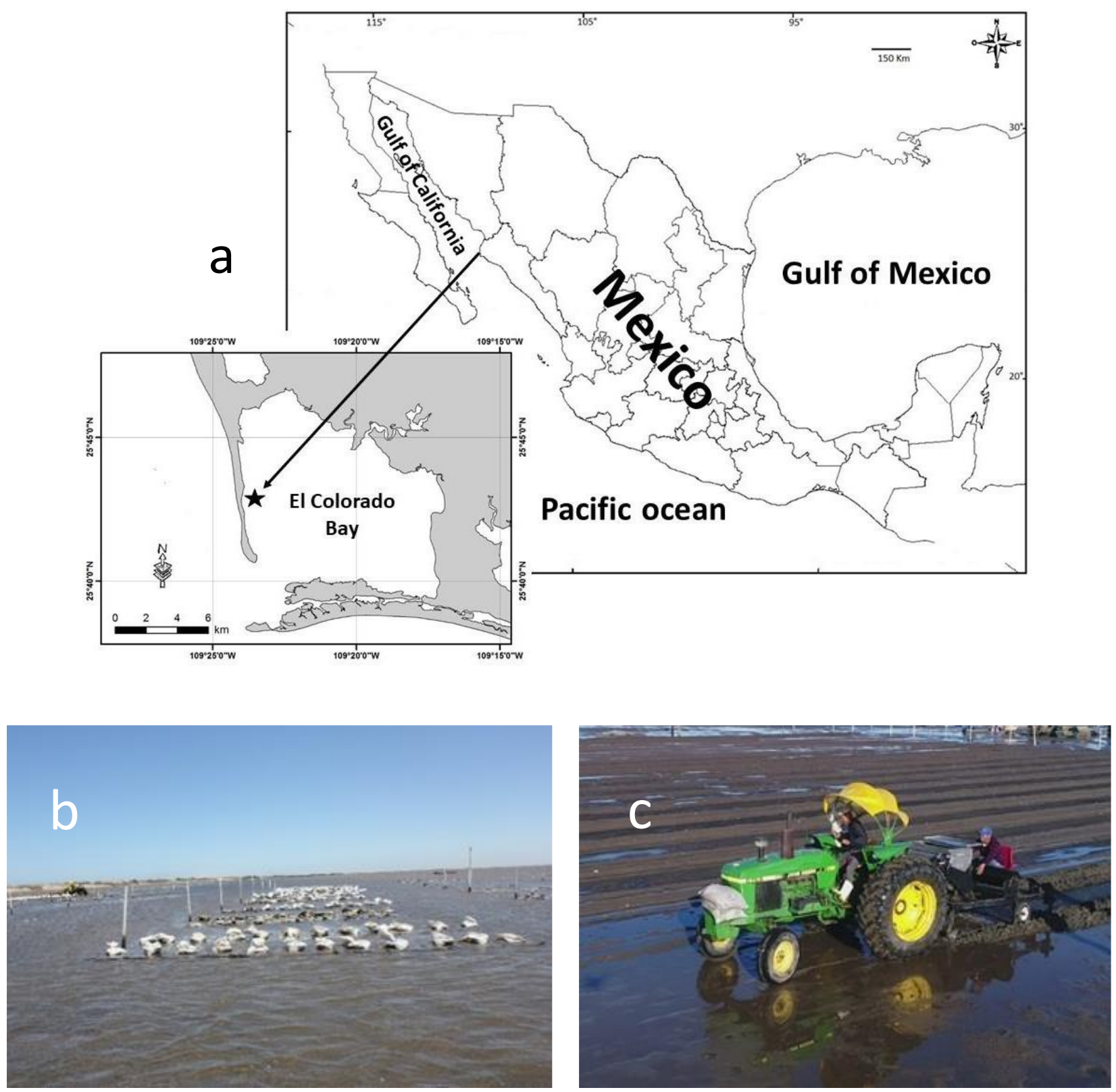

Figure 1. Geographical location of the intertidal cultivation site ( $\star$ ) in El Colorado Bay, Sinaloa, Mexico (a), pre-fattening (b) and fattening (c) of Chionista fluctifraga in the intertidal zone.

margin) was measured. Body weight (BW) was obtained with a digital scale $(0.1 \mathrm{~g})$. The clams growth rate $(\mathrm{mm} / \mathrm{d}$ and $\mathrm{g} / \mathrm{d}$ ) was estimated in both cultivation phases.

Data were subjected to the Durbin-Watson test to eliminate outliers and the residuals were analyzed to determine their normal distribution using the quantilequantile Pplot graph (Q-Q Plot) (RStudio Program, R Core Team 2018). The relationship between shell height (SH) and total body weight (BW) for total especimens $(n=960)$ and per month $(n=60)$ was estimated using the power function $\mathrm{BW}=\mathrm{aSH}^{b}$, where a=intersection and $b=$ slope. In this relationship with different units of measurement, when the exponent $b=3$, the morphometric relationship between $\mathrm{SH}$ and $\mathrm{BW}$ indicates isometric growth. With Pearson's correlation coefficient $(r)$, the goodness of fit of the data was analyzed (Sokal and Rohlf, 1981). The coefficient of variation was estimated for $\mathrm{SH}$ and $\mathrm{BW}$.
To identify significant differences in the isometric value of $b(b=3)$ or the allometric range (negative allometry $b<3$, or positive allometry $b>3$ ), a Student's $t$-test (Ho: $b=3$ ) with a $95 \%$ confidence level was used with the following equation: $t=(b-1) / S b$, where $t=$ value of the $t$-test, $b=$ slope, and $S b=$ standard error of the slope (Vasconcelos et al., 2018).

\section{Results}

\section{Environmental Parameters}

The water temperature ranged from $15.9^{\circ} \mathrm{C}$ (January 2019) to $32.1^{\circ} \mathrm{C}$ (September 2019), exhibiting a typical seasonal oscillation with the lowest gradient in winter and the highest in summer. The dissolved oxygen concentration was always greater than $5 \mathrm{mg} / \mathrm{L}$ throughout the culture (Figure $2 \mathrm{a}$ ). The highest salinity 
(40 psu) was observed in March 2019 and the lowest (25 psu) in September 2018, with an average of 34.7 psu throughout the culture; $\mathrm{pH}$ values ranged from 4.3 in August 2018 to 8.2 in March 2019 (Figure 2b).

The parameters that indicate the nutritional status of the water ( $\mathrm{Cl}-a, \mathrm{POM}$, and TSS), showed a similar pattern, with peaks in the same months of cultivation. The maximum concentration of $\mathrm{Cl}-a\left(10.5 \mathrm{mg} / \mathrm{m}^{3}\right)$ was observed in November 2018, and the minimum (2.2 $\mathrm{mg} / \mathrm{m}^{3}$ ) in August 2019. In the case of TSS, the highest concentration $(189.2 \mathrm{mg} / \mathrm{L})$ was also recorded in November 2018, whereas the lowest $(19.3 \mathrm{mg} / \mathrm{L})$ occurred in July 2018. The maximum value of POM (26.3 $\mathrm{mg} / \mathrm{L}$ ) was recorded in June 2019 , whereas the minimum $(4.8 \mathrm{~g} / \mathrm{L})$ ocurred in June 2018 (Figure 2c).

\section{Growth}

In average, the $\mathrm{CV}$ obtained for $\mathrm{SH}$ during prefattening (10.8\%) was almost four times lower that that for BW (35.6\%). The clams gained more than $400 \%$ in body weight during the two months inside the racks (Table 1).
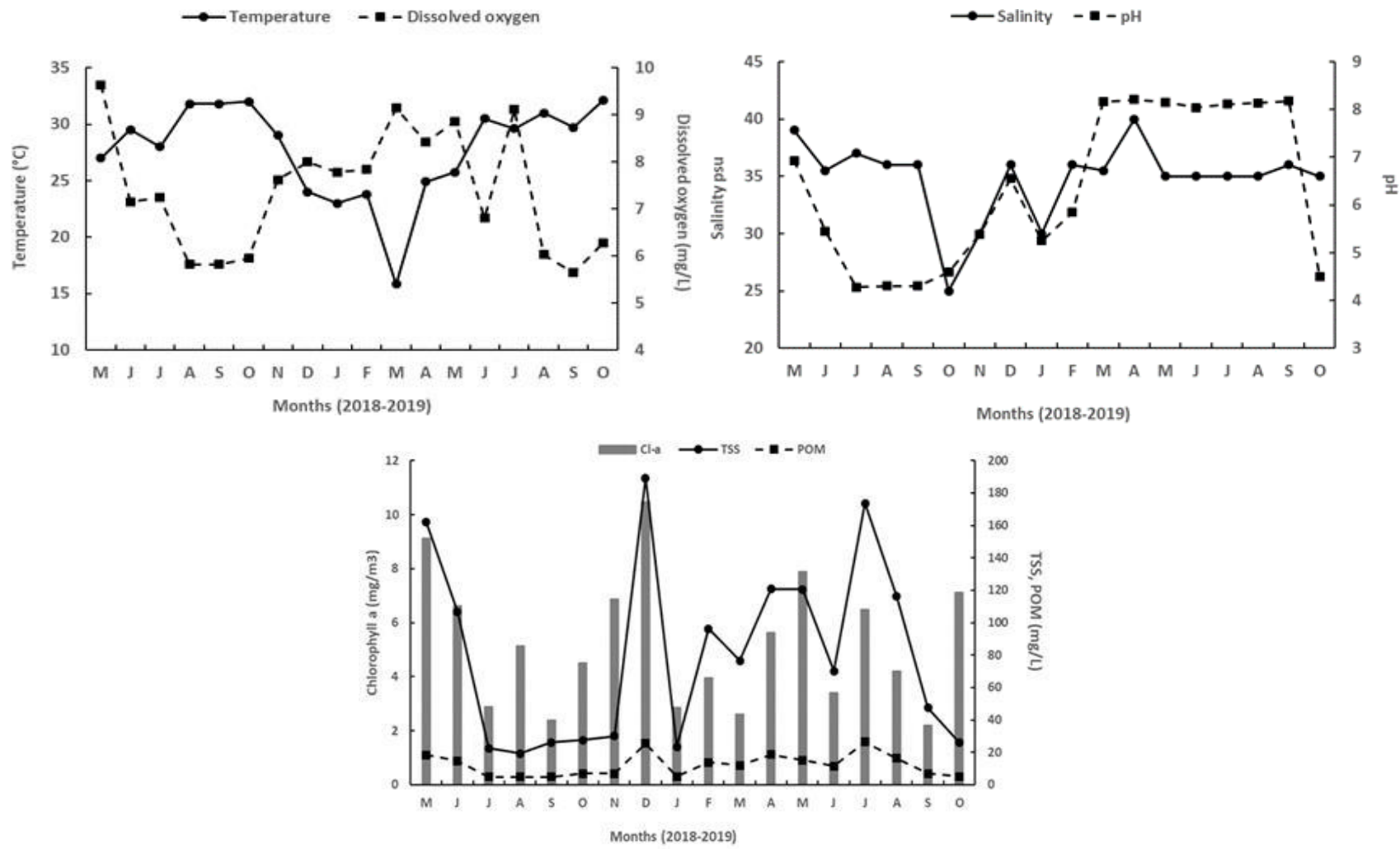

Figure 2. Monthly values of: temperature $\left({ }^{\circ} \mathrm{C}\right)$ and dissolved oxygen $(\mathrm{mg} / \mathrm{L})$; salinity $(\mathrm{psu})$ and $\mathrm{pH}$; and chlorophyll a $\left(\mathrm{mg} / \mathrm{m}^{3}\right)$, particulate organic matter $(\mathrm{mg} / \mathrm{L})$, and total suspended solids $(\mathrm{mg} / \mathrm{L})$ of water in the intertidal plot of cultivation in El Colorado Bay, Sinaloa, Mexico.

Table 1. Descriptive statistical parameters of Chionista fluctifraga cultivated within racks (60-day pre-fattening) in the intertidal zone of El Colorado Bay, Sinaloa, Mexico

\begin{tabular}{lcc}
\hline & May & June \\
\hline SH* $(\mathbf{m m})$ & & 10.57 \\
Mean & 7.2 & 1.2 \\
Standard deviation & 0.8 & 8.2 \\
Minimum & 5.4 & 13.1 \\
Maximum & 8.9 & 11.1 \\
CV & 10.5 & 0.5 \\
BW (g) & & 0.2 \\
Mean & 0.1 & 0.2 \\
Standard deviation & 0.0 & 0.9 \\
Minimum & 0.0 & 31.7 \\
Maximum & 0.2 & 39.4 \\
CV
\end{tabular}

*SH = shell height; $\mathrm{BW}=$ body weight; $\mathrm{CV}=$ Coefficient of variation. 
The scatter plot between $\mathrm{SH}$ and $\mathrm{BW}$ in the prefattening showed curvilinear relationship (Figure 3 ). The value of $b$ (3.8206) indicated positive allometry for the $\mathrm{SH}-\mathrm{BW}$ interaction.

The small clams obtained a growth rate of 0.036 and $0.109 \mathrm{~mm} / \mathrm{d}$ in SH after the first and second months of pre-fattening, respectively; meanwhile, BW increased at a rate of $0.163 \mathrm{~g} / \mathrm{d}$ in the second month of prefattening.

The average values of SH and BW of the black clam during fattening increased with time (Figure 4). The maximum value for $\mathrm{SH}$ and $\mathrm{BW}(48.36 \mathrm{~mm}$ and $50.9 \mathrm{~g}$, respectively) was recorded after 15 months of fattening (September 2019).

The monthly value of $b$ for the SH-BW morphometric interaction indicated negative allometric growth that ranged from 0.69 in July 2018 to 2.77 in January 2019 (Table 2). Except for May 2019 ( $b=1.87$, in the 11th month of fattening), the slope was greater than 2.26 as of January 2019. The determination coefficient $\left(R^{2}\right)$ presented an interval of 0.14 (July 2018) to 0.88 (October 2018).
Table 3 depicts the monthly and total growth rate of $\mathrm{SH}$ and $\mathrm{BW}$ of Ch. fluctifraga during the fattening phase. Growth decreased in all morphometric measurements with time. The clam grew $0.058 \mathrm{~mm} / \mathrm{d}$ for SH after 480 days of fattening in the sand, whereas the $\mathrm{BW}$ registered a growth rate of $0.058 \mathrm{~g} / \mathrm{d}$. A final survival rate of $90 \%$ was obtained.

\section{Discussion}

Drover (1974) and Martínez-Córdova (1988) state that the black clam is a bivalve species that tolerates low temperature gradients, but improves its performance above $20^{\circ} \mathrm{C}$. With the exception of February 2019, the water temperature in the intertidal zone exceeded this gradient, which could favor its cultivation. The temperature interval recorded in this study $\left(16-32^{\circ} \mathrm{C}\right)$ was broader than those reported by Martínez-Córdova et al. $(2011,2013)$ for the maintenance of the black clam as a bioremediator and in overwintering in shrimp ponds, and by Castillo-Durán et al. (2016) in a suspended culture. The rest of the parameters ( $\mathrm{DO}$, salinity, and $\mathrm{pH}$ )

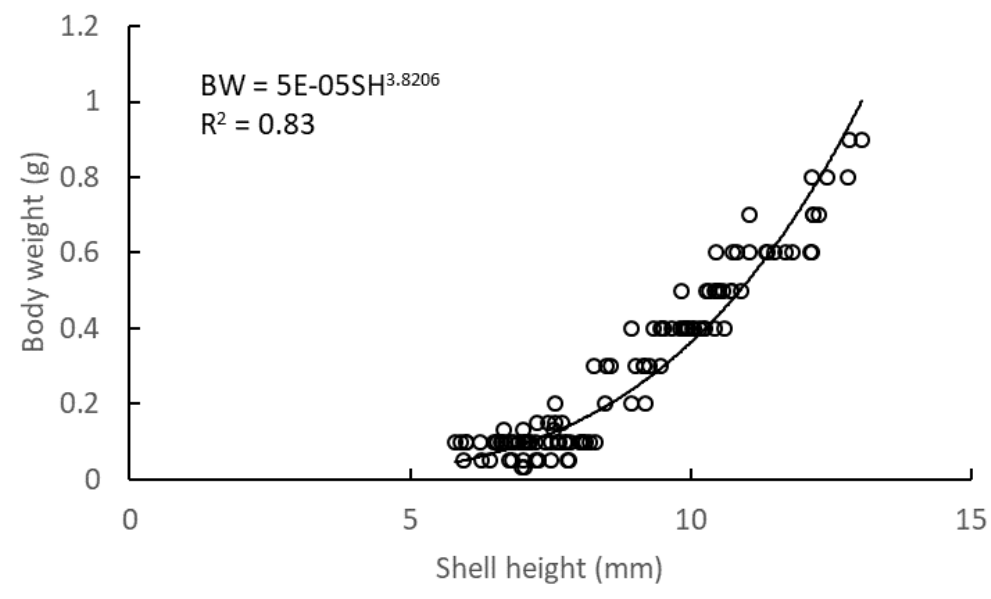

Figure 3. Morphometric relationships between shell height (SH) and body weight (BW) of the black clam (Ch. fluctifraga) cultivated in the intertidal zone of the Bahía El Colorado, Sinaloa, during pre-fattening.

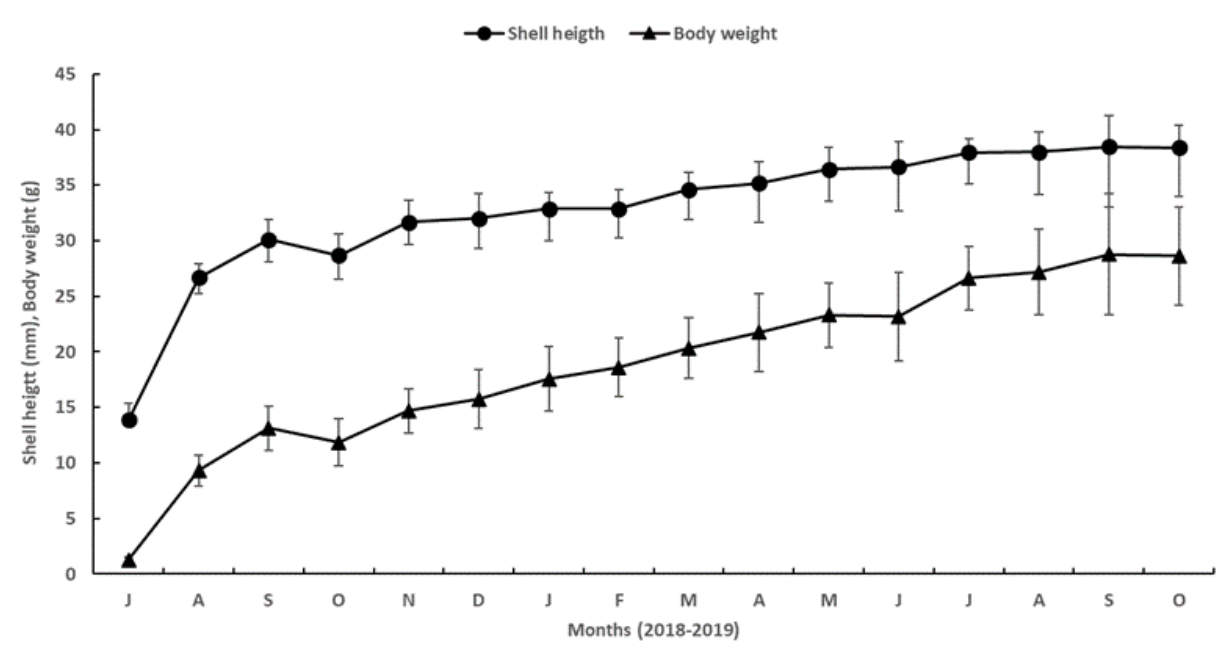

Figure 4. Shell height $(\mathrm{mm})$ and body weight $(\mathrm{g})$ of Chionista fluctifraga grown in sand (480 days) in the intertidal zone of El Colorado Bay, Sinaloa, Mexico. 
showed the same trend, which can be explained mainly by the geographical site, where El Colorado Bay, Sinaloa, is located in the Southeast of the Gulf of California. This area is characterized as climatic transition (temperatetropical, Galland et al., 2019) which could have caused the greater variability in the parameters of the study place.

Gosling (2003) mentions that the growth rate of bivalve mollusks is affected by several factors such as age and metabolism, among others, being faster in juveniles than in adults, which agrees with the observations made in the culture of Ch. fluctifraga. The SH during pre-fattening registered an increase of $71 \%$ in relation to the initial size $(6.10 \mathrm{~mm})$, presenting the same accelerated growth pattern in the first two months of fattening. The strongest morphometric interactions for each culture stage (BW-SL, $R^{2}=0.87$ in the pre- fattening phase, and BW-SH, $\mathrm{R}^{2}=0.99$ in the fattening phase) indicated positive allometry, a characteristic condition of juvenile organisms (in this case, under culture conditions), whose metabolic energy is destined to build somatic tissue and shell (Raquinia-Buban et al., 2019). Once the shell height reached $30 \mathrm{~mm}$, the monthly growth was slower until the end of the cultivation, as were documented for other bivalve species (Gangnery et al., 2003; Cassis et al., 2011).

The CV of the shell dimensions during pre-fattening was not greater than $20 \%$, but, on the other hand, the BW variation presented values higher than $30 \%$, which, for small clams, could be due to an increase in the size of the shell and improvement of their body condition (Zuarts, 1991), in addition to the intrinsic variation of the seeds (Larson et al., 2014). The morphometric relationship between $\mathrm{SH}$ and $\mathrm{BW}$ showed a positive

Table 2. Monthly morphometric relationships $(n=60)$ of the black clam Chinosta fluctifraga cultivated in the sand in the intertidal zone of El Colorado Bay, Sinaloa, Mexico

\begin{tabular}{lcc}
\hline Month & Equation & $\mathrm{R}^{2}$ \\
\hline July 2018 & $\mathrm{BW}=0.1952 \mathrm{SH}^{0.69}(0.25)$ & 0.14 \\
August & $\mathrm{BW}=0.0014 \mathrm{SH}^{2.67}(0.71)$ & 0.77 \\
September & $\mathrm{BW}=0.2269 \mathrm{SH}^{1.19}(1.80)$ & 0.21 \\
October & $\mathrm{BW}=0.0019 \mathrm{SH}^{2.59}(0.76)$ & 0.88 \\
November & $\mathrm{BW}=0.1992 \mathrm{SH}^{1.24}(1.53)$ & 0.37 \\
December & $\mathrm{BW}=0.1251 \mathrm{SH}^{1.39}(2.07)$ & 0.36 \\
January 2019 & $\mathrm{BW}=0.0011 \mathrm{SH}^{2.77}(1.90)$ & 0.46 \\
February & $\mathrm{BW}=0.0050 \mathrm{SH}^{2.35}(1.40)$ & 0.73 \\
March & $\mathrm{BW}=0.0017 \mathrm{SH}^{2.65}(1.30)$ & 0.78 \\
April & $\mathrm{BW}=0.0014 \mathrm{SH}^{2.69}(1.44)$ & 0.82 \\
May & $\mathrm{BW}=0.0273 \mathrm{SH}^{1.87}(1.91)$ & 0.62 \\
June & $\mathrm{BW}=0.0025 \mathrm{SH}^{2.53}(1.55)$ & 0.86 \\
July & $\mathrm{BW}=0.0020 \mathrm{SH}^{2.61}(1.58)$ & 0.68 \\
August & $\mathrm{BW}=0.0013 \mathrm{SH}^{2.72}(1.74)$ & 0.80 \\
September & $\mathrm{BW}=0.0073 \mathrm{SH}^{2.26}(2.41)$ & 0.80 \\
October & $\mathrm{BW}=0.0017 \mathrm{SH}^{2.66}(2.11)$ & 0.79 \\
\hline
\end{tabular}

*BW = body weight; $\mathrm{SH}$ = shell height; $\mathrm{R}^{2}$ = Coefficient of determination.

Table 3. Growth rate $(\mathrm{mm} / \mathrm{d}, \mathrm{g} / \mathrm{d})$ of Chionista fluctifraga cultivated on sand (480 days) in the intertidal zone of El Colorado Bay, Sinaloa, Mexico

\begin{tabular}{|c|c|c|}
\hline Month & $\mathrm{SH}^{*}$ & BW \\
\hline July (2018) & 0.11 & 0.03 \\
\hline August & 0.42 & 0.27 \\
\hline September & 0.11 & 0.13 \\
\hline October & -0.04 & -0.04 \\
\hline November & 0.10 & 0.09 \\
\hline December & 0.01 & 0.04 \\
\hline January (2019) & 0.03 & 0.06 \\
\hline February & 0.01 & 0.03 \\
\hline March & 0.06 & 0.06 \\
\hline April & 0.02 & 0.05 \\
\hline May & 0.04 & 0.05 \\
\hline June & 0.01 & -0.01 \\
\hline July & 0.04 & 0.12 \\
\hline August & 0.01 & 0.02 \\
\hline September & 0.02 & 0.05 \\
\hline October & -0.01 & -0.01 \\
\hline Total $(480 \mathrm{~d})$ & 0.06 & 0.06 \\
\hline
\end{tabular}


allometric growth $(b>3)$, documenting that the increase in BW is proportional to the cube of all the shell dimensions (Gaspar et al., 2001).

According to Martínez-Córdova (1988) and Castillo-Durán et al. (2016), Ch. fluctifraga reaches commercial size when its shell height presents a range of 3.5 to $4.0 \mathrm{~mm}$, demanded by the USA market. This size includes reproductively active adult specimens, with high nutritional content and better sales possibilities (Drover, 1974; Chávez-Villalba et al., 2019). In the present study, the black clam achieved this measurement $(35.19 \pm 1.88 \mathrm{~mm})$ after 12 months of cultivation ( 2 months of pre-fattening remaining inside racks placed in the sand, and 10 months of fattening sown directly in the sand), a period of time that is less than that mentioned by Martínez-Córdova (1988) of approximately 36 months, and the 18 to 36 months reported by Chávez-Villalba et al. (2019), who used wild populations to estimate commercial size. Factors such as latitude, environmental conditions of each place, and the origin of the bivalves (wild or laboratory) contribute to explain the differences in the results.

This first report on the cultivation of the black clam in the intertidal zone of Bahía El Colorado, Sinaloa, Mexico, establishes important information for future cultures, such as: 1) Ch. fluctifraga presented positive allometric growth for the SH-BW morphometric relationship in both culture phases (pre-fattening and fattening), but different growth rates; 2) since the environmental conditions in the intertidal zone did not allow obtaining the clam's BW in situ with a balance, the BW can be calculated morphometrically by simply measuring $\mathrm{SH}$; 3 ) the equation $\mathrm{BW}=0.0014 \mathrm{SH}^{2.69}$, $R^{2}=0.82$, expresses the growth of this clam when it reaches its commercial size $(35.19 \pm 1.88 \mathrm{~mm} \mathrm{SH})$ at the tenth month of fattening.

\section{Conclusion}

The SH-BW morphometric relationship was useful in optimizing harvest time of the black clam C. fluctifraga using morfometry and relative growth, when cultivated in the intertidal along the southeastern coast of Gulf of California. Finally, the possibility of reducing the fattening time from 16 months established by the private company at the beginning of this study-, to 10 months, when the commercial clam size was recorded, suggests that harvesting could be carried out in less culture time, implying, inherently, a saving in production operating expenses.

\section{Ethical Statement}

The clams were collected, transported and processed according to standard procedures (NOM-031SSA1-1993, Bienes y Servicios. Productos de la pesca. Moluscos bivalvos frescos-refrigerados y congelados). The research was approved by the Ethical Comitte of College of Professors of the IPN-CIIDIR Sinaloa.

\section{Funding Information}

This work was funded by CONACYT under grant PROINNOVA 2018, No. 250242; and IPN under grants SIP-20180665 and SIP-20190071.

\section{Author Contribution}

AMGG and JAHS, collection of clams, sampling of parameters, ans bibliographic and manuscript review. MJAC, clam harvesting, parameter sampling, and undergraduate thesis completion. MFNC, clam harvesting, sampling of parameters, and completion of masters's thesis. HRG and MIIGU, biometrics, statistical analysis, and manuscript writing. JCVF and BPVF biometrics, laboratory sample processing, and bibliographic and manuscript review, MGU, sample processing, data analysis, and manuscript writing.

\section{Conflict of Interest}

The authors declare that they have no known competing financial interests or personal relationships that could have appeared to influence the work reported in this paper.

\section{Acknowledgements}

The authors thank the National Polytechnic Institute (IPN) and CONACYT México, for their logistical and economic support. MJAC is grateful to the Autonomous University of Sinaloa for the logistic support to carry out the bachelor's degree. MFNC is grateful to the CONACYT to carry out the Master of Science studies at the Interdisciplinary Research Center for Integral Regional Development (IPN-CIIDIR-Sinaloa). Thanks to Ingrid Mascher for English edition.

\section{References}

Babaei, M.M., Sahafi, H.H., Ardalan, A.A., Ghaffari, H. \& Abdollahi, R. (2010). Morphometric relationship of weight and size of clam Amiantis umbonella L., 1818 (Bivalvia: Veneridae) In the Eastern Coasts of Bandar Abbas, Persian Gulf. Advances in Environmental Biology, 4(3), 376-382.

Biona, M.A., Marte, C.R., Pasadilla, A.L.G. \& Araneta, B.Y.G. (2017). Estimation of the edible wet tissue weight of the mangrove clam Polymesoda Erosa harvested from the wild. PEERS Inc. Multidisciplinary Research Journal, 1(1), pp. 1-9.

Cassis, D., Pearce, C.M. \& Maldonado, M.T. (2011). Effects of the environment and culture depth on growth and mortality in juvenile Pacific oyster in the Strait of Goergia, British Columbia. Aquaculture Environment Interactions, 1, 259-274. https://doi.org/10.3354/aei00025

Castillo-Durán, A., Hoyos-Chairez, F., Arreola-Lizárraga. J.A. \& Martínez-Córdoba, L. (2016). Larval and post-larval growth, spat production and off-bottom cultivation of the smooth venus clam Chionista fluctifraga. 
Aquaculture Research, 47(9), 2851-2860. https://doi.org/10.1111/are.12735

Chávez-Villalba, J., Arreola-Lizárraga, J.A. \& Castillo-Durán, A. (2019). Condition index in three size clases of the smooth venus clam Chionista fluctifraga from a commercial fishery in Sonora, Mexico. Acta Universitaria, 29, e1836. https://doi.org/10.15174.au.2019.1836

Coan, E.V. \& Valentich-Scott, P. (2012). Bivalve seashells of tropical west America. Marine bivalve mollusks from Baja California to Peru. Santa Barbara Museum of Natural History.

Drover, C.E. (1974) Seasonal exploitation of Chione clams on the southern California coast. The Journal of California Anthropology, 1(2), 224-232.

Galland, G.R., Hastings, P.A. \& Leichter, J.J. (2019). Fluctuating thermal environments of shallow-water rocky reefs in the Gulf of California, Mexico. Scientific Reports, 9, 18022. https://doi.org/10.1038/s41598-019-53730-0

Gangnery, A., Chabirand, J.M., Lagarde, F., Le Gall, P., Oheix, J., Bacher, C. \& Buestel, D. (2003). Growth model of the Pacific oyster, Crassostrea gigas, cultured in Thau Lagoon (Méditerranée, France). Aquaculture, 215, 267290.

García-Ulloa, M., Góngora-Gómez, A.M., HernándezSepúlveda, J.A. \& Astorga-Castro, O. (2018). Policultivo de moluscos bivalvos: Una experiencia en México. Panorama Acuícola Magazine, 24(1), 38-44.

Gaspar, M., Santos, M. \& Vasconcelos, P. (2001). Weightlength relationships of 25 bivalve species (Mollusca: Bivalva) from the Algarve coast (southern Portugal). Journal of Marine Biological Association of the United Kingdom, 81, 805-807.

Góngora-Gómez, A.M., Sotelo-Gonzalez, M.I., SantamaríaMiranda, A. \& García-Ulloa, M. (2018). Morphometric relationships of the siphon clam Panopea globosa (Bivalvia: Hiatellidae) in the southeasternmost of the Gulf of California, Mexico. Revista de Biología Marina y Oceanografía, 53(3), 363-366.

http://doi.org/10.22370/rbmo.2018.53.3.1366

Gosling, E. (2003). Bivalve Mollusks: Biology, Ecology and Culture. Blackwell Publishing Ltd.

Helm, M.M., Bourne, N. \& Lovatelli, A. (2006). Cultivo de bivalvos en criadero. Un manual práctico (Documento Técnico de Pesca 471). FAO.

Lavoie M.-F., McKindsey, Ch. W., Pearce, Ch. M. \& Archambault, P. (2016). Influence of intertidal Manila clam Venerupis philippinarum aquaculture on biogeochemical fluxes. Aquaculture Environment Interactions, 8, 117-130. https//doi.org/10.3354/aei00167

Larson, J.H., Eckert, N.L. \& Bartsch, M.R. (2014). Intrinsic variability in shell and soft tissue growth of the freshwater mussel Lampsilis siliquoidea. PLoS One, 9(11), e112252.

https://doi.org/10.1371/journal.pone.0112252

Martínez-Córdova, L.R. (1988). Bioecología de la almeja negra Chione fluctifraga (Sowerby, 1853). Revista de Biología Tropical, 36(2A), 213-219.

Martínez-Córdova, L.R. \& Martínez-Porchas, M. (2006). Polyculture of Pacific white shrimp, Litopenaeus vannamei, giant oyster, Crassostrea gigas and black clam, Chione fluctifraga in ponds in Sonora, Mexico. Aquaculture, 258(1), 321-326.

https://doi.org/10.1016/j.aquaculture.2006.03.026
Martínez-Córdova, Luis R., López-Elías, J.A., Martínez-Porchas, M., Bernal-Jaspeado, T. \& Miranda-Baeza, A. (2011). Studies on the bioremediation capacity of the adult black clam, Chione fluctifraga, of shrimp culture effluents. Revista de Biología Marina y Oceanografía, 46(1), 105113.

Martínez-Córdova, Luis R, Enríquez-Ocaña, L.F., López-Rascón, F., López-Elías, J.A. \& Martínez-Porchas, M. (2013). Overwintering the black clam Chione fluctifraga in a tidal shrimp pond and in an estuary, using suspended and bottom systems. Aquaculture, 396-399, 102-105. https://doi.org/10.1016/j.aquaculture.2013.02.029

Mohammed, T.A.A., Mohamed, M.H., Zamzamy, R.M. \& Mahmoud, M.A.M. (2019). Growth rates of the giant clam Tridacna maxima (Röding, 1978) reared in cages in the Egyptian Red Sea. Egyptian Journal of Aquatic Research, 45, 67-73.

https://doi.org/10.1016/jejar.20*19.02.003

Munroe, D. \& McKinley, R.S. (2007). Commercial Manila clam (Tapes philippinarum) cultiure in British Columbia, Canada: The effects of predator netting on intertidal sediment characteristics. Estuarine, Coastal and Shelf Science, 72, 319-328.

Nerlovic, V., Korlevic, M. \& Mravinac, B. (2016). Morphological and molecular differences between the invasive bivalve Ruditapes philippinarum (Adams \& Reeve, 1850) and the native species Ruditapes decussatus (Linnaeus, 1758) from the northeastern Adriatic Sea. Journal of Shellfish Research, 35(1), 1-9. https://doi.org/10.2983/035.035.0105

Ngor, P. B., Sor, R., Prak, L.H., So, N., Hogan, Z.S. \& Lek, S. (2018). Mollusc fisheries and length-weight relationship in Tonle Sap flood pulse system, Cambodia. Annals of Limnology - International Journal of Limnology, 54, 34. https://doi.org/10.1051/limn/2018026

R Core Team. (2018). R: A language and environment for statistical computing: $R$ Foundation for Statistical Computing. Vienna (Austria): The R Foundation. https://www.R-project.org/

Raquinia-Buban, I.C., Salcedo Soliman, V., Ugto Bobiles R. \& Pulvinar Camaya, A. (2019). Morpho-biometric relationship, relative condition factor and meat yield of distant scallop Bractechlamys vexillum (Reeve, 1853) in Asia Gulf, Philippines. Asian Fisheries Science, 32, 147153. https://doi.org/10.33997/j.afs.2019.32.4.002

Rice, E. W., Baird, R. B., Eaton, A. D. \& Clesceri, L. S. (2017). Solids (2540). Standard methods for the examination of water and wastewater. American Public Health Association.

Ríos-Jara, E., Esqueda-González` M. C., Michel-Morfin, J. E., López-Uriarte ${ }^{2}$ E. \& Salgado-Barragán, J. (2019). Growth and morphometric relationships of the bean clam Donax punctatostriatus Hanley, 1843 in a sandy beach of southern Sinaloa, Mexico. Latin American Journal of Aquatic Research, 47(5), 764-773. http://dx.doi.org/10.3856/vol47-issue5-fulltext-5

Saurel, C., Ferreira J. G., Cheney, D., Suhrbier, A., Dewey, B., Davis, J. \& Cordell, J. (2014). Ecosystem goods and services from Manila clam culture in Puget Sound-a modelling analysis. Aquaculture-Environment Interactions, 5, 255-270. https://doi.org/10.3354/aei00109

Sokal, R. R. y Rohlf, F.J. (1981). Biometry. WH Freeman. Strickland, J.D.H. \& Parsons, T.R. (1972). Pigment analysis: Spectrophotometric determination of chlorophylls and 
total carotenoids (Second ed). A practical handbook of seawater analysis. Fisheries Research Board of Canada.

Talley, D.M., Talley, T.S. \& Blanco, A. (2015). Insights into the establishment of the Manila clam on a tidal flat at the southern end of an introduced range in Southern California, USA. A. PLOS ONE, 10(3), e0118891. https://doi.org/10.1371/journal.pone.0118891

Toniello, G., Lepofskya, D., Lertzman-Lepofskyd, G., Salomonb, A.K. \& Rowellf, K. (2019). 11,500 y of human-clam relationships provide longterm context for intertidal management in the Salish Sea, British Columbia. PNAS, 116(44), 22106-22114. https://doi.org/10.1073/pnas.1905921116

Vasconcelos, P., Moura, P., Pereira, F., Pereira, A.M. \& Gaspar, M.B. (2018). Morphometric relationships and relative growth of 20 uncommon bivalve species from the Algarve coast (southern Portugal). Journal of Marine Biological Association of the United Kingdom, 98(3),463474. https://doi.org/10.1017/S002531541600165X

Yin, X., Chen, P., Chen, H., Jin, W. \& Yan, W. (2017).
Physiological performance of the intertidal Manila clam (Ruditapes philippinarum) to long-term daily rhythms of air exposure. Scientific Reports, 7, 41648. https://doi.org/10.1038/srep41648

Yusof, A., Sow, A.Y., Ramli, M.Z., Eh Rak, A.A/L. \& Wei, L.S. (2020). Growth performance of Asian clam Corbicula fluminea (Müller, 1774) fed with different feeds in laboratory scale culture system. Asian Fishery ScienceJournal of the Asian Fishery Society. ISSN: 0116-6514. https://doi.org/10.33997/j.afs.2020.33.1.006

Zhang, G. \& Yan, X. (2006). A new three-phase culture method for Manila clam, Ruditapes philippinarum, farming in northern China. Aquaculture, 258(1-4), 452-461. https://doi.org/10.1016/j.aquaculture.2006.04.046

Zuarts, L. (1991). Seasonal variation in body weight of the bivalves Macoma balthica, Scrobicularia plana, Mya arenaria and Cerastoderma edule in the Dutch Waden Sea. Netherlands Journal of Sea Research, 28(3), 231245. 